\title{
Medullary Thyroid Carcinoma Clinical Distant Metastasis TNM Finding v8
}

National Cancer Institute

\section{Source}

National Cancer Institute. Medullary Thyroid Carcinoma Clinical Distant Metastasis TNM

Finding v8. NCI Thesaurus. Code C141008.

A clinical finding about one or more characteristics of medullary thyroid carcinoma,

following the rules of the TNM AJCC v8 classification system as they pertain to distant metastases. 